\title{
The effect of the use of the Gail model on breast cancer diagnosis in BI-RADS 4A cases
}

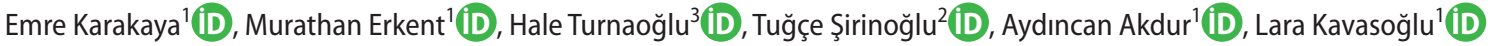 \\ ${ }^{1}$ Department of General Surgery, Baskent University Faculty of Medicine, Ankara, Turkey \\ 2 Department of Biostatistics, Medipol University Faculty of Medicine, Ankara, Turkey \\ ${ }^{3}$ Department of Radiology, Baskent University Faculty of Medicine, Ankara, Turkey
}

\begin{abstract}
Objective: The BI-RADS classification system and the Gail Model are the scoring systems that contribute to the diagnosis of breast cancer. The aim of the study was to determine the contribution of Gail Model to the diagnosis of breast lesions that were radiologically categorized as BI-RADS 4A.

Material and Methods: We retrospectively examined the medical records of 320 patients between January 2011 and December 2020 whose lesions had been categorized as BI-RADS 4A. Radiological parameters of breast lesions and clinical parameters according to the Gail Model were collected. The relationship between malignant BI-RADS 4A lesions and radiological and clinical parameters was evaluated. In addition, the effect of the Gail Model on diagnosis in malignant BI-RADS 4A lesions was evaluated.

Results: Among radiological features, there were significant differences between lesion size, contour, microcalcification content, echogenicity, and presence of ectasia with respect to the pathological diagnosis $(p<0.05)$. No significant difference was found between the lesions' pathological diagnosis and the patients' Gail score ( $p>0.05$ ). An analysis of the features of the Gail model revealed that there was no significant difference between the age of menarche, age at first live birth, presence of a first-degree relative with breast cancer, and a history of breast biopsy and the pathological diagnosis $(p>0.05)$
\end{abstract}

Conclusion: As a conclusion Gail Model does not contribute to the diagnosis of BC, especially in patients with BI-RADS 4A lesions.

Keywords: Breast cancer, breast ultrasonography, breast tumors

Cite this article as: Karakaya $E_{1}$ Erkent $M$, Turnaoğlu $H$ Şirinoğlu T, Akdur A, Kavasoğlu L. The effect of the use of the Gail model on breast cancer diagnosis in BI-RADS 4A cases. Turk J Surg 2021; 37 (4): 394-399.

\section{Corresponding Author}

Emre Karakaya

E-mail: dremrekarakaya@gmail.com

Received: 09.10 .2021

Accepted: 16.11 .202

Available Online Date: 31.12 .202

O Copyright 2021 by Turkish Surgical Society Available online at www.turkjsurg.com

DOI: $10.47717 /$ turkjsurg.2021.5436

\section{INTRODUCTION}

Breast cancer (BC) is the most common type of cancer in women and causes the highest number of deaths after lung cancer worldwide; its incidence increases by $0.3 \%$ each year (1). Early diagnosis of BC and accurate evaluation of lesions can be achieved in a greater proportion of patients thanks to recent advances in imaging modalities (2). The Breast Imaging Reporting and Data System (BI-RADS ${ }^{\circledR}$ ) facilitates communication between radiologists, clinicians, and patients using standardized lesion definitions and reports (3). Although BI-RADS 4A lesions mainly involve some atypical benign and malignant lesions, they possess a malignancy potential as low as $2-10 \%$ (4). The accepted opinion is that biopsy should be performed from BIRADS 4A lesions (5). Clinical and demographic characteristics are also used to determine the $B C$ risk. There are several risk models for assessing breast cancer risk (6-8). Among these, the most widely used one is the Gail model (GM) (7).

In the GM, risk factors are determined by interviewing the patient and a scoring is made according to the presence of these risk factors. These risk factors are; age at menarche, age at first live birth, number of biopsies per age, and number of affected relatives per age at first live birth. As a result of this scoring, the probability of women having breast cancer within five years is calculated. Patients with a probability less than $1.66 \%$ are considered low-risk, and patients with a high probability are considered high-risk. The primary purpose of the GM is to select high-risk pa- 
tients for screening and make recommendations for risk-reducing medications, rather than to diagnose $\mathrm{BC}(7,9)$.

No study in the literature has specifically evaluated BI-RADS 4A lesions in relation to clinical risk models. We aimed to determine the contribution of GM to the diagnosis of breast lesions that were radiologically categorized as BI-RADS 4A. If the pathologies of BI-RADS 4A lesions of women evaluated as low risk in terms of Gail score result in a significant majority of benign lesions, the necessity of performing a biopsy in these patients may be eliminated and the patient can be followed up clinically and radiologically at certain periods.

\section{MATERIAL and METHODS}

We retrospectively examined the medical records of 431 patients whose lesions had been categorized as BI-RADS 4A by ultrasonography and/or mammography performed at Başkent University Ankara Hospital between January 2011 and December 2020. The patients' radiological, pathological, and clinical data were obtained using hospital's data system. Patients with missing clinical and demographic information were reached via a telephone call. A total of 111 patients with an age below 18 years, previously diagnosed $B C$, and missing pathological evaluation and medical records were excluded from the study. We included 320 patients in the study.

Among patients, those under 40 years of age were examined with B-mode breast ultrasonography (USG), and those above 40 years of age were examined with mammography (MMG) and B-mode USG. In the radiological evaluation, the lesions' size, shape, orientation, contours, margins, acoustic shadowing, microcalcification content, echogenicity, structural distortion, and the presence of ductal ectasia were evaluated and recorded.

According to GM, a grouping was done by the age of menarche, age at first live birth, the number of the first-degree relatives diagnosed with $\mathrm{BC}$, and the number of previous breast biopsies to calculate the patients Gail scores (GS). Patients having a risk of greater than $1.7 \%$ were grouped as high risk, and the others as low-risk (10).

The patients' pathology reports were retrospectively reviewed from the hospital data system. According to the pathology reports, benign and malignant groups were formed. The malignant group was collected under the headings of invasive carcinoma, intraductal carcinoma, mucinous carcinoma, adenocarcinoma, and other malignant lesions while the benign lesions were collected under the headings of fibrocystic disease and adenosis, fibroadenoma and other adenomas, intraductal papilloma, inflammation, and associated lesions, benign phyllodes tumor, and benign cyst and other benign lesions.

Descriptive statistics of categoric variables were presented as number ( $\mathrm{n}$ ) and percentage (\%) and quantitative variables were presented as mean \pm S.D. Categoric variables were compared with Pearson's Chi-square test, Likelihood ratio test or Fisher's exact test, depending on the parametric test assumptions. In addition, whether the Gail score can be used to predict the pathology results was assessed using ROC (Receiver Operating Characteristic) curve with AUC (Area Under Curve) and 95\% confidence interval. Statistical analyses were performed at a significance level of $p<0.05$. All statistical analyses were performed with IBM SPSS V22 software.

\section{RESULTS}

The study included a total of 320 patients. 9.4\% $(n=30)$ of the patients had malignant lesions, and $90.6 \%(n=290)$ had benign lesions (Table 1). The mean age of the patients was $44.53 \pm$ 14.09 years. The mean age of the patients with benign lesions and those with malignant lesions was $43.87 \pm 14.10$ one years and $50.90 \pm 12.42$ years, respectively.

Among radiological features, there were significant differences between lesion size $(p=0.029)$, contour ( $p<0.001)$, microcalcification content $(p=0.009)$, echogenicity $(p=0.020)$, and presence of ectasia $(p=0.002)$ with respect to the pathological diagnosis. However, no significant difference was found between the lesion shape $(p=0.099)$, orientation $(p=0.449)$, margin $(p=$ $0.138)$, acoustic shadowing $(p=0.101)$, and presence of distortion ( $p=0.179$ ) with respect to the pathological diagnosis (Table 2).

While the size of $75.2 \%$ of benign lesions was $<2 \mathrm{~cm}, 56.7 \%$ of malignant lesions were smaller than $2 \mathrm{~cm}$. As compared with malignant lesions, a greater percentage of benign lesions had smooth contours (76.2\% vs 43.3\%). The percentage of having microcalcification was significantly higher in malignant lesions compared with benign lesions (26.7\% vs 9.3\%). The percentage of malignant lesions that showed complex echogenicity

\begin{tabular}{|c|c|}
\hline Table 1. Distribution of BI-RADS 4A lesions by pathological diagnosis \\
\hline Malignant lesions & $\mathbf{n}(\%)$ \\
\hline Invasive carcinoma & $22(6.9 \%)$ \\
\hline Intraductal carcinoma & $4(1.3 \%)$ \\
\hline Mucinous carcinoma & $0(0 \%)$ \\
\hline Adenocarcinoma & $0(0 \%)$ \\
\hline Other malignant lesions & $4(1.3 \%)$ \\
\hline Benign lesions & $\mathbf{n}(\%)$ \\
\hline Fibrocystic disease and adenosis & $42(13.1 \%)$ \\
\hline Fibroadenoma and other adenomas & $121(37.8 \%)$ \\
\hline Intraductal papilloma & $41(12.8 \%)$ \\
\hline Inflammatory and related lesions & $21(6.6 \%)$ \\
\hline Phyllodes tumor, benign & $4(1.3 \%)$ \\
\hline Cyst, benign & $14(4.4 \%)$ \\
\hline Other benign lesions & $47(14.7 \%)$ \\
\hline
\end{tabular}


Table 2. Distribution of the radiological characteristics of the lesions by pathological diagnosis

\begin{tabular}{|c|c|c|c|}
\hline Radiological parameters & Benign n (\%) & Malign n (\%) & $\mathrm{p}$ \\
\hline \multicolumn{4}{|l|}{ Lesion size } \\
\hline$<2 \mathrm{~cm}$ & $218(75.2)$ & $17(56.7)$ & \multirow[t]{2}{*}{$0.029^{*}$} \\
\hline$\geq 2 \mathrm{~cm}$ & $72(24.8)$ & $13(43.3)$ & \\
\hline \multicolumn{4}{|l|}{ Shape } \\
\hline Round, oval & $264(91)$ & $24(80)$ & \multirow[t]{2}{*}{$0.099^{\dagger}$} \\
\hline Irregular & $26(9)$ & $6(20)$ & \\
\hline \multicolumn{4}{|l|}{ Growth orientation } \\
\hline Parallel & $285(98.3)$ & $29(96.7)$ & \multirow[t]{2}{*}{$0.449^{\dagger}$} \\
\hline Nonparallel & $5(1.7)$ & $1(3.3)$ & \\
\hline \multicolumn{4}{|l|}{ Margin } \\
\hline Circumscribed & $272(93.8)$ & $26(86.7)$ & \multirow[t]{2}{*}{$0.138^{\dagger}$} \\
\hline Indistinct & $18(6.2)$ & $4(13.3)$ & \\
\hline \multicolumn{4}{|l|}{ Contour } \\
\hline Smooth, lobulated & $221(76.2)$ & $13(43.3)$ & \multirow[t]{2}{*}{$<0.001^{*}$} \\
\hline Angular & $69(23.8)$ & $17(56.7)$ & \\
\hline Acoustic shadowing & $4(1.4)$ & $2(6.7)$ & $0.101^{\dagger}$ \\
\hline Microcalcification & $27(9.3)$ & $8(26.7)$ & $0.009^{\dagger}$ \\
\hline \multicolumn{4}{|l|}{ Echogenicity } \\
\hline Anechoic-Hyperechoic & $3(1)$ & $0(0)$ & \multirow[t]{3}{*}{$0.020^{\wedge}$} \\
\hline İsoechoic-Hypoechoic & $221(76.2)$ & $16(53.3)$ & \\
\hline Complex & $66(22.8)$ & $14(46.7)$ & \\
\hline Presence of architectural distortion & $1(0.3)$ & $1(3.3)$ & $0.179^{+}$ \\
\hline Presence of duct ectasia & $89(30.7)$ & $1(3.3)$ & $0.002^{*}$ \\
\hline
\end{tabular}

characteristics was higher than that of benign lesions $(46.7 \%$ vs $22.8 \%$ ). Ductal ectasia was present in $30.7 \%$ of benign lesions and $3.3 \%$ of malignant lesions. A greater percentage of malignant lesions had an irregular shape compared with benign lesions (20\% vs 9\%). In addition, the percentage of malignant lesions with ill-defined margins was greater than that of benign lesions (13.3\% vs. 6.2\%).

No significant difference was found between the lesions' pathological diagnosis and the patients GS ( $p=0.900)$. The GS showed a low risk in $83.3 \%$ and $83.4 \%$ of patients with malignant and benign lesions, respectively (Table 3 ). In addition, our study showed that the GS could not predict cancer in BI-RADS 4A lesions ( $A \cup C(95 \%$ confidence) $=0.505$ (0.396-0.613); $p=0.934$ )

An analysis of the features of the Gail model revealed that there was no significant difference between the age of menarche ( $p=$ $0.130)$, age at first live birth ( $p=0.052)$, presence of a first-degree relative with breast cancer $(p=0.584)$, and a history of breast biopsy ( $p=0.652$ ) and the pathological diagnosis (Table 3 ).

\section{DISCUSSION}

We showed that the use of GS had no effect on the diagnosis of $\mathrm{BC}$ in the BI-RADS 4A category.

Some parameters used in the radiological evaluation of the breast lesions indicate whether a lesion is benign or malignant. These parameters are lesion shape, orientation, contours, margins, acoustic shadowing, microcalcification content, echogenicity, structural distortion, and the presence of ductal ectasia (11-13). The generally accepted opinion is that biopsy should be performed in this sub-class that possesses a malignancy potential of 2-10\% (14). In accordance with the literature, our series showed a malignancy rate of $9.4 \%$.

Niu et al. showed that, irregular lesion margins, ill-defined lesion contours, and microcalcification content on ultrasonography were related to a malignant diagnosis (13). A study reported in 2006 by Levy et al. stressed that the change of the normal pattern of seven parameters was particularly related to a malignant diagnosis. These were lesion shape, orientation, margins, con- 
Table 3. Distribution of the Gail scores and parameters by pathological diagnosis

\begin{tabular}{|c|c|c|c|}
\hline & Benign n (\%) & Malign n (\%) & $\mathrm{p}$ \\
\hline \multicolumn{4}{|l|}{ Gail score } \\
\hline High risk & $239(82.4)$ & $25(83.3)$ & $0.900^{*}$ \\
\hline Low risk & $51(17.6)$ & $5(16.7)$ & \\
\hline \multicolumn{4}{|c|}{ Age at menarche, years } \\
\hline$<12$ & $33(11.4)$ & $3(10)$ & $0.130^{*}$ \\
\hline $12-13$ & $173(59.6)$ & $13(43.3)$ & \\
\hline$>13$ & $84(29)$ & $14(46.7)$ & \\
\hline \multicolumn{4}{|c|}{ Age at first live birth, years } \\
\hline Nulliparous & $79(27.2)$ & $4(13.3)$ & $0.052^{*}$ \\
\hline$<20$ & $22(7.6)$ & $3(10)$ & \\
\hline $20-24$ & $104(35.9)$ & $13(43.3)$ & \\
\hline $25-29$ & $52(17.9)$ & $10(33.3)$ & \\
\hline$\geq 30$ & $33(11.4)$ & $0(0)$ & \\
\hline \multicolumn{4}{|c|}{ First-degree relatives with breast cancer } \\
\hline 0 & $231(79.7)$ & $26(86.7)$ & $0.584 \wedge$ \\
\hline 1 & $49(16.9)$ & $3(10)$ & \\
\hline$\geq 2$ & $10(3.4)$ & $1(3.3)$ & \\
\hline \multicolumn{4}{|c|}{ Number of biopsies } \\
\hline 0 & $243(83.8)$ & $26(86.7)$ & $0.652^{\wedge}$ \\
\hline 1 & $43(14.8)$ & $4(13.3)$ & \\
\hline$>1$ & $4(1.4)$ & $0(0)$ & \\
\hline
\end{tabular}

tours, internal echogenicity, posterior acoustic characteristics, and structural distortion (14). According to our study, significant differences were found only between the lesions' margins, microcalcification content, echogenicity, presence of ductal ectasia regarding the lesions' pathological diagnosis. The presence of more than 3 lobulations indicates the distortion of the normal anatomic structure and an irregular shape. Malignant lesions in our case series more commonly had an irregular shape although this difference wasn't statistical significance. Although benign lesions are generally reported to be oriented parallel to the skin, it has been also shown that a large proportion of malignant lesions have a parallel orientation to the skin (15). Our study found that a large proportion of lesions of both groups were oriented parallel to the skin. When lesion margins are concerned, a clear transition takes place between a benign lesion and the surrounding tissue. However, as a lesion's structure is distorted, its margins may appear ill-defined. Apart from malignancy, extremely dense or extremely fatty breasts may lead to erroneous conclusions about lesion margins (14). Although we didn't detect any significant difference, we showed that a greater proportion of malignant lesions had indistinct margins. Although acoustic shadowing is a sign indicating a lesion's ma- lignant behavior, benign lesions may also develop this feature as they develop fibrosis and calcification over time (16). Our series did not find any significant difference between malignant and benign lesions in terms of acoustic shadowing. Considering structural distortion, it has been observed that a lesion may show shrinkage or thickening due to compression and infiltration of the surrounding tissues (14). In our series, there was only one structural distortion in each group.

The Gail model was developed in 1989 by Gail and colleagues (10). According to this score, the average chance of a 60-yearold patient developing BC within five years is $1.7 \%$, which was determined as the cut-off level between high-risk and low-risk categories $(7,9,17)$. According to our hypothesis, $G M$, which is a clinical scoring system, can identify patients at high risk for BC, it may contribute to the diagnosis of breast cancer in BI-RADS $4 \mathrm{~A}$ patients by combining this risk scoring with radiological features. The reason why we chose BI-RADS 4A lesions in this study is that although the malignancy rate is very low in these lesions, biopsy is required. Gao et al. showed that the GM increased the diagnostic power of the BI-RADS classification for BC (10). In this study, it was stated that BI-RADS scoring with GM significantly contributed to the positive predictive value and accuracy in the 
diagnosis of breast cancer, especially in BI-RADS 4B lesions. In our series, GM did not affect the diagnosis of the BI-RADS 4A lesions. The fact that the malignancy rate of BI-RADS 4A lesions is only in the range of $2-10 \%$ and patients applied to our center not only for treatment but also for screening, resulted in a relatively small number of patients diagnosed with BC. To our opinion, this discrepancy results from the fact that this study was conducted at cancer centers and the study population had a greater BC risk than the general population. In addition, the fact that GM gave more accurate results in women over the age of 65 and the mean age of women in our study was less than 65 may have affected the results of the study.

The small number of patients with BC may be considered a limitation of our study. The number of patients with BC could be increased and more effective results could be obtained. Furthermore, a radiological evaluation performed by the same team in a prospectively designed study can increase its accuracy rate.

\section{CONCLUSION}

In conclusion, although the use of GM is recommended in clinical practice, our results suggest that it does not contribute to the diagnosis of $B C$, especially in patients with BI-RADS 4A lesions.

Ethics Committee Approval: This study approval was obtained form Başkent University Medicine and Health Sciences Research Committee (Decision No: KA 21/107, Date: 16.03.2021).

Peer-review: Externally peer-reviewed.

Author Contributions: Concept - E.K.; Supervision - A.A.; Materials - H.T.; Data Collection and/or Processing - M.E., L.K.; Analysis and/or Interpretation - T.S.; Literature Search - A.A.; Writing Manuscript - E.K.; Critical Reviews - E.K., A.A.

Conflict of Interest: The authors have no conflicts of interest to declare.

Financial Disclosure: The authors declared that this study has received no financial support.

\section{REFERENCES}

1. Siegel RL, Miller KD, Fuchs HE, Jemal A. Cancer statistics, 2021. CA Cancer J Clin 2021; 71 (1): 7-33. [CrossRef]

2. Yu Teng-Fei, He W, Gan Cong-Gui, Zhao Ming-Chang, Zhu Qiang, Zhang W, et al. Deep learning applied to two-dimensional color Doppler flow imaging ultrasound images significantly improves diagnostic performance in the classification of breast masses: A multicenter study. Chin Med J (Engl) 2021; 134(4): 415-24. [CrossRef]

3. Schönenberger C, Hejduk P, Ciritsis A, Marcon M, Rossi C, Boss A. Classification of mammographic breast microcalcifications using a deep convolutional neural network: A BI-RADS-Based Approach. Invest Radiol 2021; 56(4): 224-31. [CrossRef]
4. Wang Xin-Yi, Cui Li-Gang, Feng J, Chen W. Artificial intelligence for breast ultrasound: An adjunct tool to reduce excessive lesion biopsy. Eur J Radiol 2021; 138: 109624. [CrossRef]

5. Davis J, Liang J, Roh A, Kittrell L, Petterson M, Winton L, et al. Use of breast imaging-reporting and data system (BI-RADS) ultrasound classification in pediatric and adolescent patients overestimates likelihood of malignancy. J Pediatr Surg 2021; 56(5): 1000-3. [CrossRef]

6. Brinton LA, Brown SL, Colton T, Burich MC, Lubin J. Characteristics of a population of women with breast implants compared with women seeking other types of plastic surgery. Plast Reconstr Surg 2000; 105(3): 919-27. [CrossRef]

7. Gail MH, Brinton LA, Byar DP, Corle DK, Green SB, Schairer C, et al. Projecting individualized probabilities of developing breast cancer for white females who are being examined annually. J Natl Cancer Inst 1989; 81 (24): 1879-86. [CrossRef]

8. Champion VL. Instrument refinement for breast cancer screening behaviors. Nurs Res 1993; 42(3): 139-43. [CrossRef]

9. Saleh B, Elhawary MA, Mohamed ME, Ali IN, El Zayat MS, Mohamed H. Gail model utilization in predicting breast cancer risk in Egyptian women: A cross-sectional study. Breast Cancer Res Treat 2021; 188(3): 749-58 [CrossRef]

10. Gao Lu-Ying, Gu Y, Tian Jia-Wei, Ran Hai-Tao, Ren Wei-Dong, Chang $C$, et al. Gail model improves the diagnostic performance of the fifth edition of ultrasound BI-RADS for predicting breast cancer: A Multicenter prospective study. Acad Radiol 2020; S1076-6332(20)30678-4. [CrossRef]

11. Stines J. BI-RADS: use in the French radiologic community. How to overcome with some difficulties. Eur J Radiol 2007; 61(2): 224-34. [CrossRef]

12. Raza S, Chikarmane SA, Neilsen SS, Zorn LM, Birdwell RL. BI-RADS 3, 4, and 5 lesions: Value of US in management-follow-up and outcome. Radiology 2008; 248(3): 773-81. [CrossRef]

13. Niu S, Huang J, Li J, Liu X, Wang D, Zhang R, et al. Application of ultrasound artificial intelligence in the differential diagnosis between benign and malignant breast lesions of BI-RADS 4A. BMC Cancer 2020; 20(1): 959. [CrossRef]

14. Levy L, Suissa M, Chiche JF, Teman G, Martin B. BIRADS ultrasonography. Eur J Radiol 2007; 61(2): 202-11. [CrossRef]

15. Stavros AT, Thickman D, Rapp CL, Dennis MA, Parker SH, Sisney GA. Solid breast nodules: use of sonography to distinguish between benign and malignant lesions. Radiology 1995; 196(1): 123-34. [CrossRef]

16. Baez E, Strathmann K, Vetter M, Madjar H, Hackelöer B-J. Likelihood of malignancy in breast lesions characterised by ultrasound with a combined diagnostic score. Ultrasound Med Biol 2005; 31(2): 179-84. [CrossRef]

17. Rostami S, Rafei A, Damghanian M, Khakbazan Z, Maleki F, Zendehdel K. Discriminatory accuracy of the gail model for breast cancer risk assessment among iranian women. Iran J Public Health 2020; 49(11): 2205-13. [CrossRef] 


\section{ORIJINAL ÇALIŞMA-ÖZET}

Turk J Surg 2021; 37 (4): 394-399

\section{BI-RADS 4A olgularında Gail modeli kullanımının meme kanseri teşhisine etkisi}

Emre Karakaya ${ }^{1}$, Murathan Erkent ${ }^{1}$, Hale Turnaoğlu ${ }^{3}$, Tuğçe Şirinoğlu ${ }^{2}$, Aydıncan Akdur ${ }^{1}$, Lara Kavasoğlu ${ }^{1}$

1 Başkent Üniversitesi Tıp Fakültesi, Genel Cerrahi Anabilim Dalı, Ankara, Türkiye

${ }^{2}$ Medipol Üniversitesi Tıp Fakültesi, Biyoistatistik Anabilim Dalı, Ankara, Türkiye

${ }^{3}$ Başkent Üniversitesi Tıp Fakültesi, Radyoloji Anabilim Dalı, Ankara, Türkiye

\section{ÖZET}

Giriş ve Amaç: BI-RADS sınıflama sistemi ve Gail modeli meme kanseri tanısına katkı sağlayan iki skorlama sistemidir. Bu çalışmanın amacı, radyolojik olarak BI-RADS 4A olarak kategorize edilen meme lezyonlarının tanısına Gail modelin katkısını belirlemekti.

Gereç ve Yöntem: Ocak 2011 ve Aralık 2020 arasında lezyonları BI-RADS 4A olarak kategorize edilmiş 320 hastanın tıbbi dosyaları retrospektif olarak incelendi. Meme lezyonlarının radyolojik parametreleri ve Gail modele göre klinik parametreleri toplandı. Malign BI-RADS 4A lezyonları ile radyolojik ve klinik parametreler arasındaki ilişki değerlendirildi. Ayrıca, malign BI-RADS 4A lezyonlarında Gail modelin tanıya etkisi de çalışılı.

Bulgular: Radyolojik faktörler içerisinde lezyon boyutu, kontür, mikrokalsifikasyon içeriği, ekojenite ve patolojik tanı bakımından ektazi varlığı arasında anlamlı farklılıklar vardı $(p<0,05)$. Lezyonların patolojik tanıları ve hastaların Gail skorları arasında anlamlı bir fark bulunmadı $(p>0,05)$. Gail modelin niteliklerinin analizinde ilk adet yaşı, ilk canlı doğumdaki yaş, meme kanseri olan birinci derece akraba varlığı ile meme biyopsisi ve patolojik tanı arasında anlamlı bir fark bulunmadı $(p>0,05)$.

Sonuç: Sonuç olarak, Gail modeli özellikle BI-RADS 4A lezyonlara sahip hastalarda tanıya katkı sağlamamaktadır.

Anahtar Kelimeler: Meme kanseri, meme ultrasonu, meme tümörleri

Doi: $10.47717 /$ turkjsurg.2021.5436 